\title{
COMMENTARY
}

\section{Global Britain in a competitive age: strategy and the Integrated Review}

\author{
Hew Strachan
}

Abstract: Since 2010, the UK government has conducted a strategic review at five-yearly intervals, a pattern which it has maintained, at least formally, despite the strategically destabilising effects of Brexit and the Trump administration. Accordingly, on 26 February 2020 the Prime Minister announced the next iteration, albeit one which would he maintained go 'beyond the parameters of a traditional review'. COVID-19 understandably delayed the publication of the Integrated Review until March 2021. This article examines the results, using the prism of strategy to examine the review's coherence. Global Britain in a Competitive Age is as aspirational as its original ambition suggested it should be, but is light on specific policies and their delivery. The accompanying publications from the Ministry of Defence contain more substance, but their implications are not sufficiently aligned with either foreign policy or the possible eventuality of armed conflict, nor do they allow for capabilities commensurate with the scale of the task which 'Global Britain' anticipates.

Keywords: Strategy, foreign policy, defence policy, integrated operations, deterrence, resilience.

Note on the author: Sir Hew Strachan, FBA, FRSE, is Wardlaw Professor of International Relations at the University of St Andrews and an Emeritus Fellow of All Souls College, Oxford, where he was Chichele Professor of the History of War 2002-15. His books include The Direction of War: Contemporary Strategy in Historical Perspective (Cambridge, 2013), and in 2020 he published a report, with Ruth Harris, on The Utility of Force and Public Understanding in Today's Britain (RAND Europe: www.rand.org/t/RRA213-1). ORCID iD: 0000-0002-2836-4135 


\section{A 'disintegrated review'?}

Global Britain in a Competitive Age, published on 16 March 2021 with a foreword by the Prime Minister, was not the Integrated Review's sole statement on security and foreign policy. It was accompanied a week later by a Command Paper called Defence in a competitive age. Introduced by the Secretary of State for Defence, that in turn was underpinned by the Integrated Operating Concept 2025, which set out a common doctrine for all three services and had been launched by the Chief of Defence Staff on 30 September 2020. Anticipating the vocabulary which would be used both in Global Britain and in the Defence Command Paper, the Chief of Defence Staff described the United Kingdom as facing an era of persistent competition, in which 'sunrise capabilities' like cyber, big data and artificial intelligence would compensate for a diminishing number of platforms and reductions in personnel. In the tradition of the Dreadnought battleship, the long-range heavy bomber and the atomic bomb - all of which Britain had pioneered in its approach to war - the United Kingdom would maximise its firepower through innovative technologies.

Nor has the production line in fresh strategic thinking stopped with these three documents. More is to come. Defence in a competitive age promised a Defence and Security Industrial Strategy as well as a two-pronged approach to climate change, one prong to reduce defence's carbon footprint and the other to enable the armed forces to adapt better to operations in changing environments. Global Britain heralded a new international development strategy, 'a comprehensive cyber strategy' built around the National Cyber Force and an 'integrated space strategy' based on a new Space Command. Most significantly it said that the Government would start to develop 'a comprehensive national resilience strategy in 2021, in partnership with the devolved administrations and English regions, local government, the private sector and the public'. ${ }^{1}$ The two most obvious challenges to national security in 2020-21 were primarily domestic: the COVID-19 pandemic and the threat to the Union represented by the consequences of Brexit, both for Northern Ireland and the Good Friday agreement and for the boost it gave to Scottish nationalism. Although Global Britain name-checks the Union several times, it does not present a strategy for its preservation. Here, as elsewhere, the tone is aspirational, with intentions spelt out, but with specific policy and precise implementation left for later.

The accusation that follows from this proliferation of strategies, that the review was characterised more by disintegration than integration, was reinforced by the fact that the Government had pre-empted its conclusions by taking three key decisions

${ }^{1}$ HM Government (2021: 88, para 4.8). The layout of the paragraphs is not consistent across chapters, so making referencing inconsistent, and is entirely absent in the 'accessible' version. 
before its publication. On 17 June 2020 the Department for International Development was merged with the Foreign and Commonwealth Office. The implicit subordination of the place of international aid in a joined-up vision of national security was confirmed by a cut in its budget from 0.7 per cent of national income to 0.5 per cent. That reduction promises to be much higher in real terms given the drop in national income precipitated by the pandemic and to be felt particularly in conflict zones, including those in which Britain has been involved, given the prioritisation of the 'Indo-Pacific' at the expense of the Middle East and Afghanistan. The latter, Congo and Syria are confronting falls in British aid of around 60 per cent. British NGOs working to promote security and development are turning for support to governments other than that of the United Kingdom, while simultaneously finding themselves shut out from ECHO (European Civil Protection and Humanitarian Aid Operations, a funding programme worth about 1 billion euros a year) as a result of Brexit. The de-mining charity, the HALO Trust, based in Scotland and supported in her lifetime by Princess Diana, was originally set up to address Afghanistan's problems after the Soviet invasion. It has had to slash its workforce (many of them ex-Taliban fighters) by a third and those funded by the British government have fallen from 1,000 to 65. Fewer de-miners mean fewer insurgents and other former combatants in constructive employment and less safety for farmers working the land in an impoverished society. The work of such NGOs marches in step with the Ministry of Defence's proposal for persistent engagement in an era of 'constant competition'. The decision to cut the aid budget does not just undermine the claim that the policies pursued by 'Global Britain' are integrated but also robs them of effectiveness.

Two other announcements made before March 2021, both delivered on 19 November 2020, can be seen in a better light, as enablers not disablers. The creation of the National Cyber Force, a collaborative venture between GCHQ and the Ministry of Defence to counter Britain's adversaries, including states, terrorists and criminals, by both the defensive and offensive use of cyber, established a body from which strategy might flow. The Treasury's commitment of an extra $£ 24$ billion for defence over four years was welcomed by the Chief of Defence Staff as providing the headroom which will enable the Ministry of Defence to shed 'sunset' capabilities and to take risks in research and development as it searches for quality over quantity.

The most influential defence review in shaping the direction of British strategy for the post-Cold War era, that of 1998, was much lauded for being 'strategy, not Treasuryled'. Despite the $£ 24$ billion headline, the same claim cannot be made for the Integrated Review. Much of the new money does little more than reverse recent cuts. Its leading symbols, the two aircraft carriers, are a direct legacy of the 1998 review. The real problem is somewhat different. The presumption that economics are the enemy of good strategy is misplaced. The need to balance what you might like to do with what 
you can afford to do, or more realistically what you might be prepared to spend, is one of the key disciplines within strategy. It shapes priorities and so determines choices. Global Britain is characterised by a reluctance to make choices and has added commitments which it is neither equipped nor resourced to meet.

In some respects little has changed. For the time being (pending any disruption if Scotland were to become independent), Britain's geography has given its strategic posture a default position which suggests an underlying continuity. The 1998 Strategic Defence Review, which led to the orders for the two carriers, used Britain's island status to make a virtue of its global reach from a secure base in ways which find echoes in the Integrated Review. It prioritised expeditionary capabilities centred on airmaritime forces. After the wars in Iraq and Afghanistan, the 2015 National Security Strategy reverted to that posture by taking the security of the British Isles as a hub from which it could establish and project a tri-service expeditionary force. To be ready in 2025, the Joint Force was to include not just aircraft carriers and F-35 jets but also an independent British ISTAR [intelligence, surveillance, target acquisition and reconnaissance] capability and a deployable combat division.

This continuity is deceptive. It can also be read as the product of a single but major procurement decision, the commitment to build the two carriers. In 2010, when David Cameron came into office, he was persuaded that their cancellation at such a late stage would be as expensive as their continuation. Even then it remained possible until at least 2015 that only one would enter service with the Royal Navy, with the other being sold abroad. The 1998 review had been bent out of shape in 2001 by the 9/11 attacks. The government responded in July 2002 with some additional ideas on counter-terrorism in The Strategic Defence Review: A new chapter, the very title of which reflected the determination not to change course and showed a misplaced faith in continuity. The subsequent decade and a half were marked not by the use of air and sea power in rapid interventions but by protracted land warfare. Bizarrely, at no stage has British national security policy directly addressed the collective lessons of the conflicts in Iraq, Libya and Afghanistan and their implications. Although the Ministry of Defence has paid due attention to the Chilcot report on Iraq, no other government department has followed suit, and the Integrated Review dismisses Afghanistan in two separate brief, uninformative and now-outdated sentences.

In other words, strategy rarely runs in straight lines. The 2010 National Security Strategy, which had to deal with the consequences of the 2008-9 crash and was introduced by a government bent on cutting debt, was 'disintegrated' in ways not dissimilar to the Integrated Review. It too was accompanied by a separate paper on defence, the Strategic Defence and Security Review, and that in turn deferred reductions in the Army's manpower (but not in those of the other two services) until 2014, the year in which it ceased major combat operations in Afghanistan. 
In 2015 the National Security Strategy and the Strategic Defence and Security Review were folded into a single document, but that apparent unity did not prevent disintegration. The commitments undertaken in 2015 were not fully funded. The crash was predicted to come in the early 2020s with the procurement of a successor to the Vanguard-class ballistic-missile nuclear submarines. Even the Ministry of Defence conceded that its successor, the Dreadnought class, approved in 2016, would consume 6 per cent of its budget, and the problem was compounded by the pending replacement of the warheads on its missile, the US-built Trident D 5. Furthermore, at the end of 2016 Britain had to respond to the changing political context created by the Brexit referendum and the election of Donald Trump as US President. In 2017, therefore, it embarked on an update to the 2015 review, so breaking with the five-year cycle established in 2010. The result, the National Security Capability Review of March 2018, ruptured the wider security framework established by the National Security Strategy in 2010 in other ways too. The Secretary of State for Defence, Gavin Williamson, successfully fought for a separate Modernising Defence Programme, announced nine months later.

At the heart of the arguments for a unified concept of national security, expressed in 2010 not only in the National Security Strategy but also in the creation of the National Security Council and of the post of National Security Adviser, are three principles. First, security embraces not just 'hard' defence but also responses to natural disasters like floods and pandemics. Moreover, the two are not necessarily divisible: a hostile actor might well exploit the opportunities created by the latter. Second, in an era of real-time communications and social media, external and internal threats interact and feed off each other. As Gordon Brown was wont to put it when he was prime minister, British troops in Helmand were keeping the streets safe at home. Although the growth of the national security architecture was initially prompted by global terrorism undertaken by non-state actors (a topic barely touched on by the Integrated Review), the Russian attacks on the Skripals in Salisbury in 2018 made clear that this second principle had a state dimension. Third, effective responses require joint working that crosses the boundaries between government departments.

The Ministry of Defence had learnt in Iraq and Afghanistan that it had to combine military action with political effects and development projects, delivered in conjunction with the Foreign and Commonwealth Office and the Department for International Development. It called this the 'comprehensive approach'. In 2018 the National Security Adviser, Mark Sedwill, reflected his own experience in Afghanistan by developing what he called 'fusion doctrine' as a centrepiece of the 2018 National Security Capability Review. Problems which required an integrated, cross-departmental approach would be identified as such, with both funds and staff (specifically a Senior Responsible Officer) dedicated to their resolution. 
By 2020 these efforts to embed integration in Whitehall were floundering. The National Security Council itself failed to meet for long periods - and early in the pandemic not at all - and was less regularly chaired by the Prime Minister than it had been under his predecessors. Sedwill, by then Cabinet Secretary as well as National Security Adviser, found himself under attack from within government and in June 2020 the Prime Minister announced his replacement as National Security Adviser by David Frost, despite the fact that he too was already fully committed as Britain's principal Brexit negotiator. Global Britain makes just one passing reference to the 'fusion doctrine' and says little about progress towards its implementation. The Defence Command Paper mentions the need to go beyond the fusion doctrine but does not say where to. ${ }^{2}$ Neither document mentions the Joint Force. Although the carrier strike group is central to both, the deployable division is not. What is left is a deployable divisional headquarters but with one less brigade and its other capabilities in flux. The army's principal heavy-lift aircraft is being retired, it will not have a successor main battle tank until 2030, and it may no longer have armoured infantry.

\section{Strategy}

Unlike its predecessors in 2010 and 2015, Global Britain is much more explicit about strategy. 'The Government', it says immediately before its mention of the fusion doctrine, 'will need to combine a planned strategy - which sets long-term objectives, anticipates challenges along the way, and charts a course towards them - with an adaptive approach. ${ }^{3}$ When David Cameron was Prime Minister, he fought shy of such definitions and resisted the pressures exerted by his Chief of the Defence Staff to think in terms of strategy. Like many politicians he wanted to retain the flexibility to react to circumstances as they unfolded and saw strategy as a straitjacket, rather than as a springboard to adaptability. The Integrated Review establishes a strategic framework resting on four 'overarching and mutually supporting objectives': sustaining economic advantage through science and technology; shaping the open international order of the future; strengthening security and defence at home and overseas; and building resilience at home and overseas. These seem unexceptionable and unlikely to shift. However, while the Prime Minister's foreword and the Integrated Review as a whole reach out to 2030, the strategic framework's objectives are fixed only to 2025 . Presumably, therefore, they are the means which by 2030 will deliver Global Britain's long-term aims. So what are those aims?

${ }^{2}$ HM Government (2021: 19, para 2.34); Ministry of Defence (2021: 13, para 3.7).

${ }^{3}$ HM Government (2021: 19, para 2.34). 
The National Security Strategies of the last decade defined Britain's role in the world in conservative if over-arching terms. Its aim was to preserve the rules-based international order. Originally embraced by the Labour government as a unifying theme for its Defence Green Paper, published in February 2010 in advance of the election of that year, the rules-based international order became a formulation that commanded cross-party consensus. Theresa May reiterated it on several occasions when she was prime minister, not least when she went to visit the newly elected Trump in January 2017. However, repetition deprived it of resonance. It also rang hollow, sometimes domestically and certainly among non-aligned and adversarial states. Since 9/11, Britain has proved a rule breaker as much as a rule maker. In March 2003 it joined the United States in invading Iraq without the authorisation of a second UN Security Council Resolution. In 2011 it enjoyed a UN mandate to intervene in Libya but only in order to protect the non-combatant population of Benghazi, not to go on to effect regime change. These may be old charges but there are others of current relevance. One has been Britain's conduct or threatened conduct in the Brexit negotiations and in the handling of the Northern Ireland protocol, both issues settled by international agreements. Brexit too affected Gibraltar, which as a colony has no separate standing in the eyes of the EU or UN. Britain has expanded Gibraltar's habitable territory by dredging, action which in Spain's eyes is at odds with the treaty of Utrecht, which in 1713 ceded the port and fortifications but not the isthmus which connects them to the mainland. This is an issue which also weakens Britain's defence of the rules-based order in its 'competition' with China, especially with regard to the UN Convention on the Law of the Sea, to which both countries (unlike the United States) are signatories. While Britain attacks China's behaviour in the South China Sea, it rejects the UN's criticism of its own stance on the Chagos Islands and especially Diego Garcia. Such policies are not necessarily wrong or unwise, but they underline how even principled states are selective in their interpretations of the rules. The Integrated Review has now therefore concluded that 'a change of approach' is required. It believes that, because 'the international order is ... characterised by intensifying competition between states over interests, norms and values', 'preserving the postCold War "rules-based international system"' and 'a defence of the status quo' are 'no longer sufficient for the decade ahead'. Britain, it would seem, despite the line regularly adopted by the Foreign Secretary, is poised to abandon its defence of the rules. ${ }^{4}$

There is another significant change. National Security Strategies since 2010 have used a register to categorise risks, based on likelihood and impact. A pandemic was consistently rated as a tier-one risk and yet the country was caught unprepared by COVID-19, so undermining the apparent utility of the risk register. Moreover, a

\footnotetext{
${ }^{4}$ HM Government (2021: 11, para 2.5).
} 
strategy weighted towards the mitigation of threats and vulnerabilities carried other negative consequences. It made Britain slow to detect opportunities and reluctant to reap the rewards of a more adventurous approach. The narrowly military roots of strategy are relevant here. Defence tends to involve spreading resources too thinly in order to cover all eventualities; offence permits concentration of effort and the pursuit of a clear objective. It may be going too far to describe the Integrated Review as offensive rather than defensive, but it emphasises the need to preserve Britain's freedom of action in terms not simply consistent with post-Brexit ambitions but also reflective of the need to exploit opportunity by being proactive, not reactive.

Any strategy is fully tested only when put into practice; the ways in which it explains its intentions are merely words. The 'disintegration' of national strategies is not just a product of events - the 9/11 attacks in the case of the 1998 Strategic Defence Review or the COVID-19 pandemic in 2020 - but is also contingent on the determination, or otherwise, of a government to oversee their implementation. In its 2015 National Security Strategy, the Cameron government identified the 'decay and failure of key institutions' as a risk, while simultaneously introducing a referendum on Britain's membership of one such institution, the European Union. Strategy may adapt to unforeseen events and then resume course, as the definition of strategy in Global Britain suggests. Alternatively, events, however short-term their consequences, can swamp the best intentions and so have long-lived effects. Strategies which are alert to possible second- and third-order consequences are likely to prove more resilient than those which are not. Before 1982 Britain was bent on concentrating its defensive effort in Europe in order to confront the threat from the Soviet Union. Argentina saw that as its opportunity to invade the Falkland Islands, with the result that 40 years on the Falklands and their staging post, Ascension Island, remain core defence commitments in the Integrated Review.

The difficulties are compounded because strategy-making rarely follows as ordered and logical a framework as its rational models propose. This does not mean that strategy behaves irrationally. It is just that, as a collective endeavour, it is made by many hands, not a single intelligence. Global Britain, with its internal contradictions (having ditched the rules-based order, it goes on to vaunt multilateralism in terms which resurrect it, invoking 'rules' 27 times), is a particularly striking example of that tendency encapsulated in a single document. Logically top-down direction from government should result in planning and implementation by Whitehall, but the process proves more iterative than that. Most national strategies - and the Integrated Review is no exception - begin with some bottom-up thinking, especially in the Ministry of Defence. The options that emerge may then be constrained by party political pressures or by the individual politician's appetite for risk. In the case of the Integrated Review, the capacity to list options without ranking them, to express 
desirable outcomes while leaving concrete delivery to later 'strategies' and to resist matching aspiration with capability, leaves it more vulnerable than most.

\section{Strategy in practice}

Neither of the National Security Strategies of 2010 or of 2015 was explicit about the identity of its adversaries. The Integrated Review is. Global Britain names Russia as 'the most acute direct threat to the UK' and describes China 'as a systemic competitor'. The distinction in the wording is important. Much has been made of the review's 'tilt to the Indo-Pacific', as though what was promised was a reversal of the decision taken by the Labour government in 1968 to withdraw from east of Suez. In truth Britain never fully left, thanks in part to Gurkha recruitment in Nepal and training in Brunei, and it returned in force when it invaded Iraq and Afghanistan. The reliance of its oil supply and maritime trade on freedom of navigation in the Gulf and Indian Ocean has given it a persistent interest in those waters, made evident by its establishment of naval bases in Bahrain in 2014 and Oman in 2019, its retention of Diego Garcia (which was essential for its operations in Iraq and Afghanistan), and the creation of a defence staff in Singapore. What is new is the extension of these defence interests into the world's largest ocean, the Pacific. While recognising Britain's existing commitment to what it calls the 'Euro-Atlantic' region, the Integrated Review gives Britain a strategy which is more explicitly global certainly than that of $\mathrm{China}^{5}$ and arguably even of the United States.

There may be a danger of exaggeration here. The wording of Global Britain on China breaks less definitively with David Cameron's pursuit of China as a commercial and economic partner than human rights concerns over Uighurs or protests over Hong Kong might suggest. What worries Global Britain is that 'the momentum for trade liberalisation may continue to slow and cases of protectionism increase, driven by political and economic conditions within states and an increasingly aggressive use of economic and trade policy as a lever in competition between states'. Seemingly oblivious to the ironies implicit in Britain's own withdrawal from one free-trading community, it argues that 'open, trading economies like the UK will need to engage with China and remain open to Chinese trade and investment, but they must also protect themselves against practices that have an adverse effect on prosperity and security'. ${ }^{6}$ China, in other words, is presented as both an economic competitor and a trading partner, but not as a military threat. However indirect its choice of words,

${ }^{5}$ See Fravel (2019) for the geographical focus of China's strategy.

${ }^{6} \mathrm{HM}$ Government (2021: 26, chapter 3) (there are no para numbers in this chapter). 
Global Britain seems to accept that it cannot have it both ways - and that is true not just of China, but also of those it seeks as regional allies, whose proximity to an increasingly assertive hegemon makes them wary of overtly hostile posturing, not least by those who might wish to present themselves as allies, like Britain.

Defence in a competitive age sees China differently. It treats China, as well as Russia, as a military competitor. Presenting China's rise as 'by far the most significant geopolitical factor in the world today', it identifies its navy as the world's largest and warns that in the air it will soon have 'a full spectrum' of capabilities. China's military modernisation is, it says, 'proceeding faster than any other nation' and its behaviour in the Indo-Pacific region is 'increasingly assertive'. ${ }^{7}$ Led by the Royal Navy, this militarisation of Anglo-Chinese relations has been under way for some time, albeit with surprisingly little challenge or debate. In February 2019 Gavin Williamson said that HMS Queen Elizabeth, the first of the aircraft carriers, would be deployed to the South China Sea. The Prime Minister's foreword to the Integrated Review, which confirmed that the carrier strike group would pass through the Mediterranean and on to the Indo-Pacific in 2021, was less explicit. Defence in a competitive age, by advertising the carrier strike group's integration with the US Navy and US Marine Corps, implied a British readiness to support the United States within what China calls 'the first island chain'.

All four of Britain's 'five-eyes' intelligence-sharing partners are Pacific powers. For some time, three of them, Canada, New Zealand and Australia, have been balancing their defence relationship with the fifth, the US, with their economic interests. As they have cleaved to America for security, they have turned to China for trade. Other Pacific powers located closer to Asia's mainland, from Singapore through to the Philippines and then Japan, have been behaving similarly. China's assertiveness and, in particular, its explicit claim to Taiwan have made this balancing act increasingly hard to sustain. The United States has responded by imposing a form of deterrence in the western Pacific which relies on very rapid escalation in order to manage a crisis which could emerge at any moment. Talk of a renewed Cold War in Europe misses the point in relation to east Asia: here, as the Demilitarized Zone in Korea testifies, the Cold War never ended. Peace has not been fully established and its maintenance rests on a hair-trigger. ${ }^{8}$

Those dangers, coupled with economic imperatives, mean that the rising tensions are in turn causing rifts among the democratic powers. New Zealand has refused to bow to US pressure to see 'the five-eyes partnership' as a military alliance in embryo; its ANZAC partner, Australia, has gone the other way, proving ready to jeopardise its

${ }^{7}$ Ministry of Defence (2021: 5, paras 1.1, 1.5; 9, paras 2.3, 2.4).

${ }^{8}$ See Caverley \& Dombrowski (2020). 
trade with China in pursuit of increasingly robust conventional deterrence. Despite its physical distance, Britain has advertised its desire to be part of a Pacific alliance. The Prime Minister floated the idea of a NATO for the Pacific and the Defence Command Paper calls on NATO to respond to the 'systemic threat' posed by China. It also mentions bilateral relations with South Korea and the plan to create a defence staff in Canberra. Recent press articles have floated possible British alliances with Japan and even with Taiwan, although the latter is not even a formal ally of the United States. ${ }^{9}$

The carrier strike group therefore bears a heavy burden of foreign policy expectation. It signals to the United States that Britain is ready to support it in the Pacific just as Britain assumes that the US will honour its maritime obligations in the 'Euro-Atlantic'. The facts, that in military terms the carrier strike group makes only a marginal difference to the naval balance in the western Pacific and that its presence would probably hamper the escalatory mechanics of US deterrence in the event of a crisis, seem to be less important than the attractions of the carrier group's capacity for 'influence' with regional allies and other democratic powers. The United States would probably prefer the United Kingdom to 'back-fill' in areas closer to home in order to offset the overstretch to which even the US is subject. That would cut the Royal Navy's carbon emissions and the massive fuel costs incurred by such deployments. The Integrated Review is silent on how frequent they will be. Defence in a competitive age asserts that the carrier strike group is 'permanently [emphasis added] available to NATO, an embodiment of an unwavering commitment to the defence and deterrence of the Euro-Atlantic area'. ${ }^{10}$ That statement is immediately contradicted in the following sentence, which describes the carrier strike group's deployment to the Indo-Pacific. All the eye-catching attention devoted to the carriers neglects the fact that they are accompanied by frigates, destroyers and other assets regularly and routinely required in the 'Euro-Atlantic'. They have to be present to be effective, whether the purpose is to defend or to deter, and they cannot be in two different oceans at the same time. This is 'gesture strategy'. It is also deeply dangerous, giving mixed messages to allies and adversaries alike, and risking war by accident and inadvertence.

\section{The strategic implications of operational concepts}

The Integrated Operating Concept provides a doctrine for a joint force capable of fighting simultaneously in five domains - land, sea, air, cyber and space - with converging effects. The doctrine's components are mutually reinforcing and intellectually

${ }^{9}$ For an alternative approach, see Porter \& Mazarr (2021).

${ }^{10}$ Ministry of Defence (2021: 14). 
self-sufficient. As a result, the Integrated Review process was characterised by an unusual degree of unanimity among the chiefs of staff, with inter-service rivalry notable by its absence. That may have been assisted by COVID-19, which focused press attention elsewhere and gave few opportunities for informal networking and single-service lobbying, but it was also helped by the conversion of Joint Forces Command into Strategic Command and its emergence - not least through its development of the Integrated Operating Concept - as a primus inter pares among the single-service chiefs.

The vision of armed conflict on which the Integrated Operating Concept and its product, Defence in a competitive age, rest relies on technological innovation as a force multiplier. The regular army, whose strength is set at 72,500, will be weaker in manpower terms than at any point since 1792 . When that point is made, commentators rarely also observe that the navy has probably never had so few platforms in its entire existence. Such comparisons are dismissed on the grounds that the personnel of today's armed forces are better educated and more skilled than their predecessors, and that the systems they operate are more capable and more lethal than even those of three decades ago, let alone three centuries. In a hot war today, small forces can be disproportionately more effective than they were in the two world wars or even in the 1st Gulf War. However, similar advantages apply to the peer competitors against whom such capabilities need to be matched. The British armed forces are not seeking relative advantage over the enemies of yesterday but those of today and tomorrow. The Integrated Operating Concept rests on the assumption that forces themselves do not have to be massed in order to concentrate their fires; it also relies on the very high kill probabilities conferred by satellite intelligence and precision guidance. Such a heavy reliance on the control of cyberspace would become a vulnerability were it lost, with secure connectivity forfeit and forces fighting blind. Moreover, the premium put on engaging the enemy at a distance, which in turn might justify the possible gaps in the capability of the deployable division, is at odds with the recent experience of heavy fighting at close quarters in urban areas. ${ }^{11}$

Given that the Defence Command Paper assumes that its two principal adversaries are major states possessed of considerable military sophistication, this technocratic vision of armed conflict may be sustainable in terms of tactics and operations. It is supported too at the strategic level by its assumption - asserted with less equivocation than in any recent National Security Strategy - that Britain would not be fighting alone. The question is with whom. The more the United States has recognised the limitations on its power, opting in consequence for its own 'tilt' to the Indo-Pacific, the more desperate has been the United Kingdom's embrace and the more muddled its

\footnotetext{
${ }^{11}$ See King (2021).
} 
relations with its European allies. Given that, the Integrated Review could have advocated greater role and capability specialisation within NATO, to which Britain itself contributes with the carrier strike group and its plans to introduce new SSBNs. Instead it maintains the appearance of a 'full-spectrum' and 'balanced' force, albeit without the scale implicit in such adjectives.

None of this means that the Integrated Operating Concept does not carry strategic opportunity costs. Like other allies, Britain compromises its own freedom of action when it commits itself to collective defence. That has long been explicit in the 'EuroAtlantic' thanks to its commitment to NATO's Article 5. The United States, having widened the geographical reach of Article 5 eastwards in the aftermath of the Cold War, now wants to extend it again to embrace Ukraine, so increasing the risks of escalation and further complicating its security relationship with Russia. Britain, in its determination to be a loyal ally and effective partner of the United States, seems anxious to go even further by adding the Indo-Pacific, a so-called 'region' which effectively embraces not only half the world, but also its largest ocean and its busiest sea. Nor does 'Global Britain' end there: it puts no clear geographical limit on where it might fight. Defence in a competitive age, reflecting the thinking in the Integrated Operating Concept, says it aims to evolve

from a force that is primarily designed for the contingency of a major conflict and warfighting, to one that is also designed for permanent and persistent global engagement. To succeed in the era of systemic competition we will need to be front-footed. We and our allies and partners must drive the tempo of strategic activity rather than responding to others. That requires a different way of thinking. It requires as much focus on how the force is postured and used as on its structure. It requires a mindset that is based on continuous campaigning, seeing all activity as part of an overall operational design. ${ }^{12}$

Applied globally, such a vision, given its commitment to recurrent unaccompanied postings to potentially volatile locations, carries profound implications for serving personnel in terms of what used to be called 'harmony guidelines'. There is little use in having a workforce that is highly skilled and professionally educated if it cannot be retained, and pragmatic and sensible reforms, like lateral entry and career breaks, may prove to be no more than palliatives. Small but elite forces have little inherent slack. In recent years, much time and effort have been devoted to bringing the armed forces back to the UK, to integrating them and their families in civilian life, to encouraging them to find permanent homes, and to ensuring - through enshrining the Armed Forces Covenant in law - that they suffer no disadvantage.

${ }^{12}$ Ministry of Defence (2021: 12, para 3.6). 
Here, however, the concern is more with the strategic logic inherent in the notion of 'continuous campaigning'. The proposal is that, by engaging early in potential trouble spots, the armed forces can act pre-emptively by establishing defence partnerships in other countries, by training the forces of those that need assistance, and by signalling a readiness to act in areas of the world where Britain shores up deterrence. None of this is credible unless it is reinforced and upheld by the readiness to fight if required. Training others' armed forces relies - as the British Army learned in Iraq and Afghanistan - on being ready to accompany them into battle and, if necessary, to kill and be killed. It also risks backing a state whose commitment to democratic norms may not be consonant with the 'rules' which Britain says it supports, such as human rights or the rejection of torture. It might create an army prepared to topple its own government or to change sides in a civil war. Nor is it clear that the vision sketched out in Global Britain has recognised the domestic political consequences of a proposed force structure that could put British service personnel in harm's way in countries of which the electorate knows little and about which it may care less.

What the doctrine does not make entirely clear is which are the opponents that 'continuous campaigning' is designed to thwart in an era of 'constant competition'. At one level it suggests that the 'global war on terror', now more conventionally rebranded as the 'long war', goes on - and it does, in Sahel, the Horn of Africa, Mozambique and the Middle East. It looks likely to persist in Afghanistan. The Integrated Review was published before the US decision to withdraw from the latter by September 2021, and Britain, in company with other European allies, has quietly indicated - or at least both the Chief of the Defence Staff and the head of MI6 have done so publicly, even if ministers have been silent - its disappointment. But if pre-empting international terrorism at its source is the objective of the Integrated Operating Concept, that aim is not much in evidence in either Global Britain or the Defence Command Paper. Because the context here dwells on state competitors using 'hybrid war', 'grey-zone warfare' and cyber, 'continuous campaigning' seems targeted more at countering subversion and proxy warfare of the sort used by Russia, Iran and China below the level of open warfare. Parallels with the so-called 'global Cold War', waged by the US and the Soviet Union in Latin America, the Middle East and subSaharan Africa come to mind. The questions begged by the Integrated Operating Concept are twofold. The first is a general one: whether one size will fit all conditions, irrespective of distance, culture, economic development and regional context. Is 'continuous campaigning' designed to suppress terrorists and insurgents in the Horn of Africa or to deter China by supplementing the plans of the US Marine Corps to conduct 'expeditionary advanced base operations' in the islands of the western Pacific? The second relates to whether, if the doctrine fails to contain the problems which it is designed to address, Britain is ready to escalate its response. The Integrated Operating 
Concept might require Britain, not its adversaries, to be the first to use actual violence.

The strategic implications go further. The statements in Global Britain and Defence in a competitive age on nuclear deterrence make clear - logically enough - that nuclear weapons will be integrated in Britain's vision for fighting major wars. The expanded geographical reach of British ambitions has been cited as one reason why the Integrated Review abandoned the intention to reduce the number of Britain's nuclear warheads to 180 and instead proposed to increase them to a possible maximum of 260 . Others have suggested that the higher figure may be a signal to the US as Britain brings the Dreadnought class into service and as America reviews its options for new nuclear warheads. In 1982 Britain, which relies on the US for its nuclear warheads and had planned its programme around the Trident I or C 4 missile, was caught out by Washington's decision to retire it prematurely in favour of the D 5. Either way, the point remains that British deterrence, while it rests on conventional capabilities in the first instance, resides ultimately in nuclear weapons. Extending the geographical range over which conventional forces are distributed, while reducing their numbers, lessens the credibility of their deterrent effects short of war. It also limits their capacity to sustain losses if war becomes protracted. Both tendencies could steepen and shorten the ladder of escalation to the nuclear level.

The Integrated Review therefore demands a more substantive discussion on nuclear deterrence than that to which Britain has become accustomed. The 'tilt to the Indo-Pacific' takes Britain to a region where there is not just one adversarial nuclear power, Russia, but two. Moreover, they and the United States are not the only nuclear-armed players in the area; India and Pakistan have to be taken into account as well. Cold War debates come to mind. How far can the umbrella of nuclear escalation be spread? Europeans were distrustful of the US concept of extended deterrence, calculating that in reality no president would place US cities at risk of a retaliatory second strike if there were a Soviet attack in Europe. By the same token, it is hard to see an Asiatic power putting its faith in the credibility of a deterrent based in the United Kingdom - or at least not without sufficient evidence of a sustained British commitment to Pacific security, with perhaps a consequent derogation of that in the Euro-Atlantic. Certainly it would need more than an occasional visit by a carrier strike group.

On the other hand the US might change its Cold War position. During the Cold War, London argued that the British independent nuclear deterrent would complicate the decision-making of NATO's adversaries in a crisis. Then the US tended to poohpooh the case for a 'second finger on the trigger', but today Washington finds its own resources stretched. It also confronts an inflection point in the strategy surrounding nuclear weapons, with the suspension of the Intermediate-Range Nuclear Forces 
(INF) agreement in 2019. In one of his first actions as president, Joe Biden agreed to Russia's request that the two powers renew the Strategic Arms Reduction Treaty (START), to reduce nuclear weapons. But China is not party to START - and nor is Britain. These considerations heighten the risks of inadvertent escalation or miscalculation in a region where the stabilising effects of the Cold War legacy have not left the same mark as in Europe. By the same token, however, such fears in turn - at least in the paradoxical world of nuclear weapons theory - themselves reinforce deterrence.

Is nuclear deterrence how the Integrated Review will square its strategic circle? Britain is developing forces which are more effective but smaller for a strategy that embraces not one continent but two (and possibly more), not one of the world's oceans but both (and a melting Arctic as well), and takes on two major opponents at the same time. It could find itself confronting both Russia and China simultaneously, either because they decide to make common cause or, more probably, because Russia would exploit the opportunities in Europe which a Pacific crisis might present. It is not clear that Global Britain in a Competitive Age has grasped these realities, or - if it has - that Britain is ready to communicate them in such blunt terms to its adversaries or to its allies, or even to its own people. As well as defining strategy, another novelty of the review is that it makes unfashionably frequent use of the word diplomacy. Rather than drive Russia and China together, it might be sensible to disaggregate them, using diplomacy to achieve détente with at least one, and - given the extreme perils involved - ideally both.

\section{Acknowledgements}

I am very grateful to Dr David Blagden of the University of Exeter for his comments and suggestions; to Major General James Cowan and Chris Loughran of the HALO Trust; and to Sir Adam Roberts who reviewed this article with his customary perspicacity.

\section{References}

Caverley, J.A. \& Dombrowski, P. (2020), 'Cruising for bruising: maritime competition in an anti-access age', Security Studies, 29: 671-700.

Fravel, M.T. (2019), Active defense: China's military strategy since 1949 (Princeton, Princeton University Press).

King, A. (forthcoming, 2021), Urban warfare in the 21st century (Cambridge, Polity Press).

HM Government (2021, March), Global Britain in a Competitive Age: the Integrated Review of Security, Defence, Development and Foreign Policy, CP403. https://www.gov.uk/government/publications/ global-britain-in-a-competitive-age-the-integrated-review-of-security-defence-development- 
and-foreign-policy/global-britain-in-a-competitive-age-the-integrated-review-of-securitydefence-development-and-foreign-policy

Ministry of Defence (2020, 30 September), Introducing the Integrated Operating Concept. https://www.gov.uk/government/publications/the-integrated-operating-concept-2025

Ministry of Defence (2021, March), Defence in a competitive age, CP411. https://assets.publishing. service.gov.uk/government/uploads/system/uploads/attachment_data/file/974661/CP411_Defence_Command_Plan.pdf

Porter, P. \& Mazarr, M. (2021), Countering China's adventurism over Taiwan: a third way (Sydney, Lowy Institute Analysis).

To cite the article: Hew Strachan (2021), 'Global Britain in a competitive age: strategy and the Integrated Review', Journal of the British Academy, 9: 161-177. DOI https://doi.org/10.5871/jba/009.161

Journal of the British Academy (ISSN 2052-7217) is published by The British Academy, 10-11 Carlton House Terrace, London, SW1Y 5AH www.thebritishacademy.ac.uk 
